\title{
Pengaruh Bimbingan Belajar (Les di Luar Sekolah) Pada Prestasi Belajar IPA Siswa Kelas VIIII MTs Jabal Noer Geluran Sidoarjo
}

\author{
Aziza Anggi Maiyanti ${ }^{1{ }^{*}}$,Ummiy Fauziah Laili) \\ ${ }^{1) 2}$ Institut Agama Islam Negeri Kediri, Indonesia \\ 1)maiyantiazizaanggi@gmail.com, ${ }^{2}$ ummiyfauziyahlaili@iainkediri.ac,id,
}

\begin{tabular}{l}
\hline open \\
access \\
*Penulis Korespondensi \\
\hline Histori Artikel: \\
Submit: 2022-01-26 \\
Diterima: 2022-01-27 \\
Dipublikasikan: 2022-02-01 \\
\hline Kata Kunci: \\
Pendidikan; Sains; Komputer \\
(minimal 5 kata)
\end{tabular}

\begin{abstract}
ABSTRAK
Penelitian yang berfokus pada hasil belajar bidang studi IPA ini berujuan untuk mengetahui adakah pengaruh dari bimbingan belajar atau les yang diikuti beberapa siswa di suatu lembaga di luar jam sekolah pada hasil belajarnya di bidang studi IPA. Tindakan observasi penelitan dilakukan di MTs Jabal Noer Geluran Taman Kabupaten Sidoarjo yang menyasar pada kelas VIIII tahun ajaran 2020-2021 alasan peneliti mengambil penelitian pada kelas VIIII tahun ajaran 2020-2021 karena belum melaksanakan PTS ataupun ujian akhir semester. Dalam penelitain, peneliti mengggunakan jenis penelitian kuantitatif. Adapun populasi yang diambil dalam penelitian terkait adalah semua siswa kelas VIIII MTs Jabal Noer Geluran. Data yang dikumpulkan peneliti untuk penelitian ini adalah menggunakan dokumentasi berupa nilai siswa dan teknik wawancara bebas. Selanjutnya model analisis data yang dipakai oleh peneliti adalah statistik Tes "t". dari penelitian ini menghasilkan adanya pengaruh les pada hasil belajar peserta didik dalam bidang studi IPA dan menunjukan adanya signifikansi nilai peserta didik yang mengikuti les dengan peserta didik yang tidak ikut les di luar jam sekolah. Hasil ini diperoleh setelah menghitung $t$ hitung sebesar 2,23 dan membandungkannya dengan $t_{\text {tabel }}$ pada taraf signifikansi $5 \%$ yaitu 2,069. Dengan pengajuan hipotesis $H_{0}$ tidak ada signifikansi nilai antara peserta didik yang ikut les dengan peserta didik yang tidak ikut les ditolak.
\end{abstract}

Komputer is licensed under a Creative Commons AttributionNonCommercial 4.0 International (CC BY-NC 4.0).

\section{LATAR BELAKANG}

Pendidikan dalam suatu rumusan nasional dalam UU RI No. 2 Tahun 1989, Bab I, Pasal 1 adalah sebagai berikut: "Pendidikan adalah usaha sadar untuk menyiapkan peserta didik melalui kegiatan bimbingan, pengajaran, dan atau latihan bagi peranannya di masa yang akan datang". Selain belajar, pendidikan juga memiliki komponen lain selain belajar. Komponen ini berupa pembelajaran. Gagne (1977) mengemukakan salah satu konsep pembelajaran adalah bahwa pembelajaran merupakan rancangan berbagai peristiwa dari sisi eksternal pembelajaran untuk mendukung proses internal pembelajaran. Teori dari gagne ini disajikan lebih komplit lagi dengan simpulan bahwa proses pembelajaran dirancang guna membuahkan hasil dalam proses belajar setiap individu. Agar tercapai tujuan dari belajar dan pembelajaran itu, suasana belajar yang menyenangkan sangatlah berpengaruh dalam peningkatan hasil belajar peserta didik.

Dalam pendidikan untuk mencapai tujuan dari pendidikan itu, siswa yang berperan menjadi subjek didalamnya bisa berorientasi pada suatu lembaga pendidikan baik formal maupun informal. Adapun pendidikan formal adalah pendidikan yang sudah disusun dengan struktur dan kurikulum sedemikian rupa yang mana pendidikan formal ini adalah pendidikan yang berjenjang atau bertingkat mulai dari tingkat dasar, pertengahan sampai tingkat tinggi. Sedangkan pendidikan informal yaitu suatu pendidikan selain 
pendidikan formal, ini berarti pendidikan informal pelaksanaanya tidak diatur oleh struktur tertentu, tidak ada kurikulum khusus dan tidak bertingkat seperti bimbingan-bimbingan belajar, kursus, dan lain sebagainya.

Membicarakan tentang berbagai mata pelajaran, diantara banyak macam mata pelajaran yang menarik unuk diulas adalah bidang studi IPA, yang dinilai menjadi bidang studi rumit dan sangat sulit bagi sebagaian peserta didik. IPA pada hakikatnya adalah suatu kajian ilmu, yang berisi suatu konsep dasar dengan pengembangan menggunakan cara berpikir, yang memadukan antara metode, dan beberapa alat yang mengggambarkan, menetapkan dan memyelesaikan suatu permasalahan, Mata pelajaran IPA merupakan salah satu disiplin keilmuan yang menempati posisi utama pada bidang pendidikan. IPA dalam pelaksanaan pendidikan diajarkan tingkat dasar yaitu tingkat SD, pada tingkat SMP, dan pada tingkat atas yakni SMA, sampai pada tingkat perkuliahan.

Untuk mengatasi permasalahan di atas, secara spesifik bagaimana hasil belajar seorang anak tidak berada di bawah yang seharusnya, baik dari segi intelektual, perasaan, hasil psikomotorik, maupun bagaimana siswa dapat bertahan selama belajar di sekolah, adalah penting. Untuk mendapatkan pertimbangan luar dalam khususnya pada mata pelajaran IPA yang terkesan merepotkan dan melelahkan, ada baiknya seorang anak diberikan suatu pemberian bimbingan agar mereka lebih menarik dan mahir dalam belajar dan mereka dapat membuat kemajuan belajar dan tentunya meraka dapat mencapai keberhasilan dalam belajar yang dapat mereka banggakan. Sebenarnya, yang wajib mendidik anak adalah orang tuanya, setelah anak mendapatkan pelajaran di sekolah hal ini tidak dapat dipungkiri lagi sebab anak lebih banyak mengahabiskan waktunya bersama di lingkungan keluarganya. Sekolah sebagai tempat belajar sekunder bagi mereka hanya memberi layanan belajar kurang lebih $1 / 4$ hari, selebihnya anak menghabiskan waktu di lingkungan keluarganya.

Namun, banyak orang tua yang tidak bisa menemani anaknya dalam belajar karena berbagai alasan, demi memperoleh capaian belajar maksimum untuk anaknya orang tua memilih mendaftarkan putranya dalam pendampingan belajar tambahan seperti mengikuti bimbingan les privat lembaga atau perseoranagan. Berdasarkan hasil wawancara bersama guru wali kelas VIIII yang peneliti lakukan, ada tiga alasan mengapa orang tua mereka melakukan hal tersebut yaitu: Pertama, orang tua tidak mampu menguasai ilmu yang wajib diajarkan pada anaknya. Kedua orang tua. Tidak memilik lebih banyak waktu untuk menemani belajar putranya lantaran orang tua mulai sibuk bekerja di luar tempat tinggalnya. Ketiga, pedagogi pada tempat tinggal tidak nyaman dikantong orang tua. Namun, dari terlepas dari semua itu, masih ada sebagian orang tua yang membimbing belajar anaknya sendiri di rumah dengan sebaik-baiknya. untuk itu demi mencapai penguasaan hasil belajar topik IPA, banyak orang tua peserta didik memutuskan mengambil les atau bimbingan belajar untuk putra putrinya diluar jam pendidikan formal. Dari latar belakang permasalahan ini, peneliti tertarik untuk mengetahui pengaruh les di luar sekolah terhadap prestasi belajar siswa kelas VIIII khususnya kelas VIIII MTs Jabal Noer Geluran Taman Sidoarjo pada pelajaran IPA.

\section{a. Prestasi}

\section{STUDI LITERATUR}

Oemar Hamalik (1990:21) memaparkan menjelaskan bahwa dalam kaitannya dengan keterlibatan dan praktik, prestasi atau pencapaian adalah jenis perkembangan atau perubahan yang dikomunikasikan oleh seorang individu dalam cara berperilaku yang baru. Selanjutnya, Sadiman. A. M (2009: 46) 
mengatakan bahwa prestasi adalah kapasitas asli, yang merupakan konsekuensi dari kerjasama dari berbagai elemen dalam dan luar yang mempengaruhi interaksi belajar individu.

\section{b. Belajar}

Menurut Irwanto (1997:105) Belajar adalah suatu proses tidak pernah bisa dan terjadi di jumlah waktu tertentu. Belajar juga merupakan proses perubahan karakter setiap individu, adanya perubahan ini diwijudkan melalui peningkatan kualitas dan jumlah perilaku, seperti meningkatkan dari aspek kognitif pengetahuan, keterampilan, memperbaiki tindakan kepribadian, mengubah kebiasaan, dan meningkatkan pemahaman, mengasah kemampuan dalam berpikir serta potensi-potensi lainnya.

\section{c. Prestasi Belajar}

Prestasi Belajar dalam pandangan Winkel (2012), prestasi adalah bukti keberhasilan dari suatu aktifitas yang telah dicapai. Dari sudut pandang ini, bisa dimengerti jika prestasi merupakan suatu buah dari kerja keras setiap individu. Prestasi belajar dalam bahasa inggris di ungkapkan dengan kata “achievement". Sedangkan dalam Bahasa Indonesia sendiri dikatakan sebagai prestasi. Namun karena kata tersebut berasal dari kata "toachieve" yang artinya tercapai, sering kali diterjemahkan menjadi "achievement" atau "segala sesuatu yang telah dicapai". Prestasi merupakan suatu pencapaian yang didapatkan semua orang untuk memaksimalkan perolehandari kegiatan dan pekerjaannya. Uji potong lintang yang dipimpin oleh Triastuti (2016) memperoleh bahwa ada hubungan positif antara faktor ketersediaan belajar dan prestasi belajar. Pengujian yang terkait dengan hubungan antara pengetahuan dan prestasi belajar juga dilakukan oleh Ahvan and Pour (2016) dan Laidra, Pullmann, dan Allik (2007). Ahvan and Pour (2016) memperkirakan wawasan 270 siswa sekolah menengah menggunakan instrumen jajak pendapat Douglas dan Damage yang terdiri dari 80 hal penjelasan. Hasil tinjauan ini menunjukkan bahwa ada hubungan positif dan kritis $(\mathrm{p}<0,05)$ antara pengetahuan dan prestasi belajar siswa sekolah menengah di Bandar Abbas.

\section{d. Bimbingan Belajar}

Bimbingan belajar adalah suatu proses membantu orang (siswa) mengatasi masalah yang dihadapinya dalam belajar sehingga pada saat proses pembelajaran dimulai, mereka dapat mencapai hasil belajar yang optimal sesuai dengan kemampuan, bakat dan minatnya serta dilaksanakan untuk menunjang program pendidikan. Prayitno dan Erman Amti (fauziyyah:2017) menunjukkan bahwa konseling adalah proses di mana beberapa ahli memiliki dukungan ahli. Bimbingan belajar adalah suatu proses untuk membantu orang (siswa) mengatasi masalah yang dihadapinya dalam belajar sehingga setelah proses pembelajaran dimulai dapat mencapai hasil belajar yang optimal sesuai dengan kemampuan, bakat dan minatnya serta mendukung program pendidikan.

\section{e. Prestasi Belajar IPA}

Dari uraian tentang belajar, prestasi, hasil, dan IPA yang ada pada uraian kajian teori yang telah penulis paparkan, dapat di tarik kesimpulan tentang apa itu hasil belajar IPA. Hasil belajar IPA adalah hasil yang telah dicapai dalam rangka usaha untuk mendapatkan perubahan secara keseluruhan dalam bidang studi IPA. 


\section{METODE}

Tempat dan waktu Penelitian: Penelitian ini dilaksanakan di MTs Jabal Nur Geluran Kecamatan Taman Kabupaten Kediri. Dan dilakukan observasi langsung pada jumat, 13 oktober 2021

Metode Penelitian: Dalam penelitian ini peneliti menggunakan metode penelitian deskriptif yaitu metode deskriptif kuantitatif, Penelitian kuantitatif merupakan hasil penelitian yang dilakukan dalam bentuk digital melalui perhitungan statistik. Metode penelitian ini digunakan untuk mengetahui apakah partisipasi siswa dalam bimbingan belajar berpengaruh terhadap hasil belajar IPA melalui nilai PTS mereka. Adapun yang menjadi variabel bebas $(X)$ pada penelitian ini adalah nilai PTS IPA yang mengikuti les. Sedangkan variabel terikat (y) dalam penelitian ini adalah nilai PTS IPA KI-4 siswa yang tidak mengikuti les. Variabel yang mempengaruhi atau menyebabkan berubahnya atau tinggalnya variabel.

Populasi dan Sampel: Adapun populasi dalam ulasan ini adalah siswa kelas VIIII di MTs Jabal Noer dengan 25 siswa mengikuti les. Sugiono (2007) menuturkan bahwa total sampling merupakan metode pengambilan sampel dimana jumlah sampel sesuai dengan jumlah populasi keseluruhan. Sampel dalam ulasan ini adalah 25 siswa kelas VIIII MTs Jabal Noer. Sedangkan variabel menurut Arikunto (2010:320) ada 2 yaitu "variabel independent (bebas) adalah variabel yang memperjelas atau mempengaruhi variabel yang lain. Dan variabel dependen (terikat) adalah variabel yang diperjelas atau dipengaruhi oleh variabel bebas". Dalam hal ini variabel bebasnya atau disebut dengan variabel independent nya adalah X dan variabel terikatnya adalah Y.

Teknik Pengumpulan Data: Dalam penelitian ini, peneliti mengumpulkan data melalui dokumentasi, dan wawancara. Dokumentasi adalah teknik pengumpulan data yang tidak ditampilkan langsung kepada subjek penelitian, melainkan rekaman peristiwa yang valid. Dokumen dapat berupa gambar tertulis atau karya monumental yang dapat berupa gambar seperti foto, dan lainnya. Dalam penelitian ini dokumen yang digunakan yaitu Penilaian Tengah Semester siswa kelas VIIII (TA 2020/2021) MTs Jabal Noer dan foto bukti penelitian.

Teknik Analisis Data: Teknik yang digunakan peneliti adalah teknik statistik Tes " $\mathrm{t}$ ", dimana data yang sudah di peroleh oleh peniliti dianalisis dengan sampel besar $(\geq 25)$ yang tidak berkorelasi, untuk mengetahui apakah ada signifikasi nilai hasil belajar IPA siswa yang mengikuti lembaga bimbingan belajar di luar jam sekolah dengan hasil belajar siswa yang tidak mengikuti les. Dengan teknik ini juga nantinya untuk mengetahui apakah ada pengaruh les pada nilai matemaatika siswa kelas VIIII TA 2020-2021 MTs Jabal Noer. Dalam teknik ini rumus yang akan digunakan adalah

$$
t_{o}=\frac{M_{x}-M_{y}}{\sqrt{\left(\frac{S D_{x}}{\sqrt{N-1}}\right)^{2}+\left(\frac{S D_{y}}{\sqrt{N-1}}\right)^{2}}}
$$

Sebelum mencari $t_{o}$ kita akan mencari mean dan standar deviasi dari kedua variabel dengan rumus berikut: $M_{x}=\sum \frac{F_{x}}{N}$ untuk Mean $M_{x}$, dan untuk mean $M_{y}$ menggunakan rumus $M_{y}=\sum \frac{F_{Y}}{N}$

Adapun untuk mencari standar deviasi masing-masing variabel rumusnya: 


$$
\begin{aligned}
& S D_{x}=\sqrt{\frac{f x^{2}}{N}-\left[\frac{f x}{N}\right]^{2}} \\
& S D_{Y}=\sqrt{\frac{f y^{2}}{N}-\left[\frac{f y}{N}\right]^{2}}
\end{aligned}
$$

Keterangan:

$M_{x} \quad=$ Rumus mencari mean untuk variabel $\mathrm{X}$

$M_{Y} \quad=$ Rumus mencari mean untuk variabel $\mathrm{Y}$

$S D_{x} \quad=$ Rumus untuk mencari stanadar deviasi variabel $\mathrm{X}$

$S D_{Y} \quad=$ Rumus untuk mencari standar deviasi pada variabel $\mathrm{Y}$

Uji hipotesis dari penelitian tentang apakah ada pengaruh les pada hasil belajar IPA siswa kelas VIII MTs Jabal Noer Geluran Taman atau tidak dengan

$H_{0}=P=0$, Tidak terdapat perbedaan yang signifikan antara nilai hasil belajar IPA siswa yang mengikuti les dengan nilai siswa yang tidak mengikuti les.

$H_{1}=P \neq 0$, Ada perbedaan yang signifikan antara nilai siswa yang mengikuti les dan tidak mengikuti les.

\section{HASIL}

Deskripsi Lokasi Penelitian: MTs Jabal Noer terletak di Geluran Kecamatan Taman Kabupaten Sidoarjo Terdapat 7 ruangan di sekolah ini dengan 15 staf pengajar beserta kepala sekolah. Adapun dalam sistem pembelajaran, sekolah ini menggunakan sitem kurikulum 2013 sebagimana aturan kemendikbud nomor 54 tahun 2013 tentang standar kurikulum pembelajaran Tetapi, ditengah masa pendemi ini, kurikulum pembelajaran yang dipakai adalah kurikulum darurat sebagaimana aturan yang dikeluarkan oleh kemendikbud nomor 719/P/2020.

Deskripsi Data: Dalam penelitian ini ada 2 variabel yaitu variabel $(\mathrm{X})$ untuk menyatakan hasil siswa yang mengikuti les atau bimbingan belajar, dan variabel (Y) untuk menyatakan hasil belajar siswa kelas VIII MTs Jabal Noer yang tidak mengikuti les. Adapun data siswa kelas VIII TA 2020/2021 MTs Jabal Noer yang mengikuti les di suatu lembaga diluar sekolah sebanyak 14 anak dari jumlah keseluruhan sebanyak 25 anak. Data ini diperoleh dengan menanya lansung kepada semua siswa kelas VIII TA 2020/2021 dan guru wali kelasnya saat observasi. Sedangkan data yang dianalisis adalah data hasil belajar (PTS) IPA KI4 siswa kelas VIII TA 2020/2021 MTs Jabal Noer yang diperoleh dari nilai Penilaian Tengah Semester mata pelajaran IPA tematik KI-4, dengan kriteria ketuntasan minimal pada materi IPA di sekolah tersebut adalah $\geq 65$.

Deskripsi Waktu Pelaksanaan Penelitian: Penelitain ini dilaksanakan selama 1 hari pada jam sekolah aktif selama 1 jam untuk wawancara dan pengumoulan dokumentasi pada hari Rabu tanggal 13 Oktober 2021. Peneliti meminta izin kepala sekolah dan melengkapi administrasi persyaratan untuk melakukan penelitian tersebut kepada sekolah yang bersangkutan. Objek penelitian terfokus pada siswa kelas VIII MTs Jabal Noer TA 2020-2021. 
Penyajian Data : Data yang akan disajikan dibawah ini adalah data dari pengumpulan data yang berupa wawancara dan dokumentasi. Wawancara ini dilaksanakan pada hari yang sama bersama guru wali kelas dan siswa kelas VIII TA 2020-2021. Adapun data yang diperoleh dari dokumentasi dengan meminta kepada guru wali kelas VIII, akan disajikan dalamtabel frekuensi di bawah ini:

Tabel 1. Hasil Dokumentasi Sebaran Siswa

\begin{tabular}{ccccc}
\hline $\begin{array}{c}\text { Interval } \\
\text { Nilai }\end{array}$ & $\begin{array}{c}\text { Ikut } \\
\text { Les }\end{array}$ & $\begin{array}{c}\text { Frekuensi } \\
\text { Tidak Ikut } \\
\text { Les }\end{array}$ & $\begin{array}{c}\text { Persentase \% } \\
\text { Ikut } \\
\text { Les }\end{array}$ & $\begin{array}{c}\text { Tidak } \\
\text { Ikut } \\
\text { Les }\end{array}$ \\
$78-80$ & 2 & 5 & $14,2 \%$ & $45,4 \%$ \\
$81-83$ & 2 & 2 & $14,2 \%$ & $18,1 \%$ \\
$84-86$ & 7 & 3 & $50 \%$ & $27,7 \%$ \\
$87-89$ & 2 & 1 & $14,2 \%$ & $9,09 \%$ \\
$90-92$ & 1 & 0 & $7,1 \%$ & $0 \%$ \\
Jumlah & $\mathbf{1 4}$ & $\mathbf{1 1}$ & $\mathbf{1 0 0 \%}$ & $\mathbf{1 0 0 \%}$ \\
\hline
\end{tabular}

Frekuensi nilai PTS KI-4 IPA siswa yang mengikuti les tertinggi berada pada kelas ke-3, dengan kisaran nilai antara 84-83, yaitu sebanyak 7 siswa,. Frekuensi terendah yaitu 1 siswa terjadi pada interval ke-5 dengan rentang skor 90-92. Frekuensi terbesar siswa yang tidak mengikuti les terdapat pada interval pertama dengan rentang nilai 78-80 yaitu sebanyak 5 siswa, dan frekuensi terendah pada interval ke-5 dengan rentang nilai 90-92, dengan jumlah 0 (tidak ada siswa yang menerima skor). Adapun persentase nilai IPA KI-4 ditunjukkan pada tabel histogram di bawah ini.

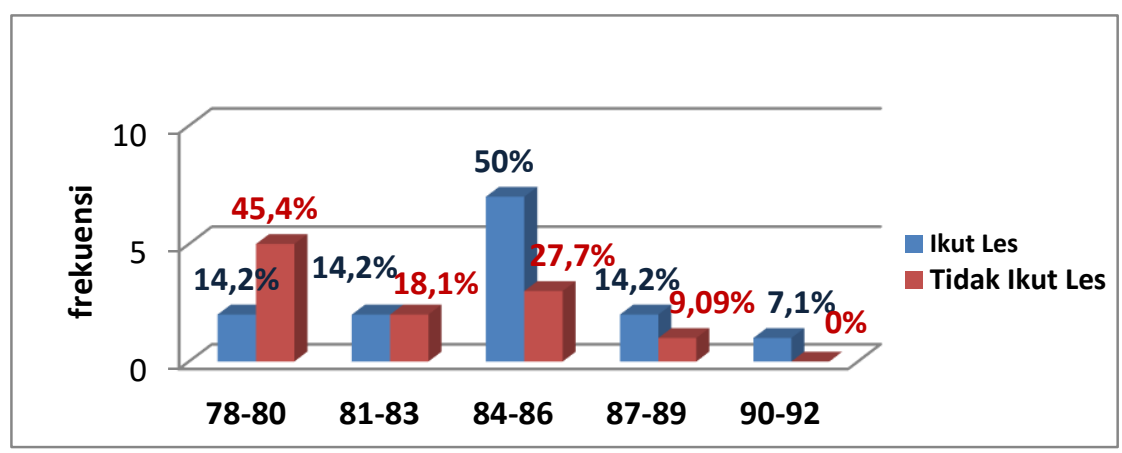

Gambar 1. Nilai IPA KI-4

Siswa yang mengambil les dengan rentang nilai 84-86 memiliki persentase tertinggi yaitu $50 \%$, Sedangkan siswa yang mengambil les dengan rentang nilai 90-92 sebaliknya, memiliki persentase terendah yaitu 7,1\%. Persentase siswa yang tidak mengikuti les terbesar berada pada kisaran nilai 78-80 yaitu 45,4 $\%$. Siswa dengan rentang nilai 90-92 mendapatkan persentase $0 \%$ yakni tidak ada siswa yang tidak mengikuti les dengan rentang nilai tersebut.

Kemudian untuk menemudahkan penelitian, penulis akan mengelompokkan dan memerinci siswa yang mengikuti les dan siswa yang tidak mengikuti les. Berikut rekapitulas hasi PTS siswa yang mengikuti les atau bimbingan belajar.

Tabel 2. Rekapitulasi Nilai PTS IPA K1- 4 Siswa yang mengikuti Les 


\begin{tabular}{rlr}
\hline No & Nama & Nilai \\
1 & Annisa Rahmania Azzahra & 86 \\
2 & Derlian Angga Rizhendry & 80 \\
3 & Elviana Elizabeth & 85 \\
4 & Maulani Al jawi & 87 \\
5 & Muhammad Nur Rizky & 85 \\
6 & Muhammad Azril Kafa Bihi & 90 \\
7 & Meysa Kirana Oktaviani & 85 \\
8 & Nabila Mufida & 86 \\
9 & Nesya Aurelie Putri & 89 \\
10 & Reyhan Kalil Ziadan & 80 \\
11 & Reni Sesiliana & 82 \\
12 & Ririn Duwi Suryanti & 85 \\
13 & Rizky Abraham Pratama & 85 \\
14 & Syeril Agnesia Wafa & 80 \\
\multicolumn{2}{c}{ Jumlah } & $\mathbf{1 1 8 8}$ \\
\hline
\end{tabular}

Dari tabel rekapitulasi nilai PTS siswa diatas dapat kita lihat, nilai tertinggi siswa yaitu 90 yang di dapat oleh responden nomor 6 . Sedangkan nilai terendahnya adalah 80 dengan 3 responden. Dan berikut adalah data siswa yang tidak mengikuti les.

Tabel 3. Rekapitulasi Nilai PTS IPA K1- 4 Siswa yang tidak mengikuti Les

\begin{tabular}{rlr}
\hline No & Nama & Nilai \\
1 & Aura Nurida Khuroatul Aini & 84 \\
2 & Alfia Fauzia Azzahra & 88 \\
3 & Dhani Dwi Handika & 78 \\
4 & Dinda Amelia Agustin & 78 \\
5 & Icasia Aulia Ivana & 84 \\
6 & Kirana Seza Nabella & 79 \\
7 & Naila Alfi Muna & 82 \\
8 & Putri Ayu Maulidia & 82 \\
9 & Rendi Putra Pengarep & 80 \\
10 & Usnaida Manna Azzahra & 78 \\
11 & Zayyin Fatoni Arifin & 78 \\
\multicolumn{2}{c}{ Jumlah } & $\mathbf{8 9 7}$ \\
\hline
\end{tabular}

PEMBAHASAN

Data yang sudah diperoleh diatas akan dianalisis menggunakan Tes " $t$ " untuk sampel besar $(\geq 14)$ guna mengetahui apakah terdapat signifikasi hasil belajar IPA siswa yang mengikuti les dengan siswa yang tidak mengikuti les. Juga untuk mengetahui pengaruh les di lembaga luar sekolah tersebut terhadap hasil belajar siswa. Variabel pada Tes " $t$ " ini ada 2 yaitu variabel $\mathbf{X}$ untuk hasil belajar IPA siswa yang mengikuti les di luar sekolah, sedangkan variabel yang ke dua yaitu variabel $\mathbf{Y}$ untuk hasil belajar IPA siswa yang tidak mengikuti les di kelas VIII MTs Jabal Noer. Data yang sudah ada di tabulasikan menjadi tabel distribusi frekuensi sebulum menganalisis dengan Tes " $\mathrm{t}$ ". berikut tabulasi tabel distribusi tersebut 
Tabel 4. Frekuensi Nilai PTS IPA KI-4 Siswa yang Mengikuti Les di Luar Sekolah

\begin{tabular}{cc}
\hline Nilai Siswa & Frekuensi (f) \\
90 & 1 \\
89 & 1 \\
87 & 1 \\
86 & 2 \\
85 & 5 \\
82 & 1 \\
80 & 3 \\
\hline
\end{tabular}

Tabel 5. Frekuensi Nilai PTS IPA KI-4 Siswa yang Tidak Mengikuti Les di Luar Sekolah

\begin{tabular}{cc}
\hline Nilai Siswa & Frekuensi (f) \\
88 & 1 \\
84 & 2 \\
82 & 2 \\
80 & 1 \\
79 & 1 \\
78 & 4 \\
\hline
\end{tabular}

Sebagaimana hipotesis alternatif dan hipotesis nihil yang sudah di rumuskan diatas dijelaskan $H_{0}=P=0$, tidak terdapat perbedaan yang signifikan antara nilai hasil belajar IPA siswa yang mengikuti les dan tidak. $H_{1}=P \neq 0$, terdapat perbedaan yang signifikan nilai siswa yang mengikuti les dan tidak mengikuti les. Maka untuk menganalisis data dengan Tes " $\mathrm{t}$ " prosedurnya sebagai berikut:

Sebelum menghitung $t_{o}$ dengan rumus yang sudah dijabarkan yaitu

$$
t_{o}=\frac{M_{x}-M_{y}}{\sqrt{\left(\frac{S D_{x}}{\sqrt{N-1}}\right)^{2}+\left(\frac{S D_{y}}{\sqrt{N-1}}\right)^{2}}}
$$

Langkah-langkah yang harus dipersiapakan terlebih dahulu ialah menghitung variabel $\mathrm{X}$ dan $\mathrm{Y}$ dengan perhitungan pada tabel berikut:

Tabel 6. Variabel X

\begin{tabular}{cccc}
\hline $\begin{array}{c}\text { Nilai Siswa } \\
(\mathbf{x})\end{array}$ & $\begin{array}{c}\text { Frekuensi } \\
\text { (f) }\end{array}$ & FX & $F X^{2}$ \\
90 & 1 & 90 & 8100 \\
89 & 1 & 89 & 7921 \\
87 & 1 & 87 & 7569 \\
86 & 2 & 172 & 29586 \\
85 & 5 & 425 & 180625 \\
82 & 1 & 82 & 6724 \\
80 & 3 & 240 & 57600 \\
\hline
\end{tabular}




\begin{tabular}{cccc}
\hline Jumlah & $\mathbf{N}=\mathbf{1 4}$ & $F X=\mathbf{1 1 8 5}$ & $F X^{2}=\mathbf{2 9 8 1 2 5}$ \\
\hline
\end{tabular}

Tabel 7. Variabel Y

\begin{tabular}{cccc}
\hline $\begin{array}{c}\text { Nilai Siswa } \\
(\mathbf{y})\end{array}$ & $\begin{array}{c}\text { Frekuen } \\
\text { si (f) }\end{array}$ & FY & $F Y^{2}$ \\
88 & 1 & 88 & 176 \\
84 & 2 & 168 & 28224 \\
82 & 2 & 164 & 26896 \\
80 & 1 & 80 & 6400 \\
79 & 1 & 79 & 6241 \\
78 & 4 & 312 & 97344 \\
Jumlah & $\mathbf{N}=\mathbf{1 1}$ & $F X=\mathbf{8 9 1}$ & $F Y^{2}=\mathbf{1 6 5 2 8 4}$ \\
\hline
\end{tabular}

Setelah perhitungan varaiabel X dan Y selesai selanjutnya adalah menghitung maean dan standar deviasi dari Variabel X dan Y.

a) Mean dan standar deviasi variabel $\mathrm{X}$

Untuk mencari mean dari variabel $\mathrm{X}$ kita gunakan rumus $\mathrm{M}_{\mathrm{x}}$ dengan $\mathrm{N}=14$, dan $f x=1185$ maka mean dari variabel $\mathrm{X}$ adalah 84,64 . Sedangkan standar deviasi dari variabel $\mathrm{X}$ dengan menggunakan rumus (2) menghasilkan 118.87.

b) Mean dan Standar Deviasi Variabel Y

Untuk mencari mean variabel $\mathrm{Y}$ kita gunakan rumus $\mathrm{M}_{\mathrm{Y}}$ dihasilkan nilai 81. Untuk mencari standar deviasi variabel Y kita gunakan rumus (3) menghasilkan 92. Setelah mengetahui masing-masing mean dan standar deviasi dari variabel $\mathrm{X}$ dan $\mathrm{Y}$, selanjutnya menentukan $t_{o}$ dengan rumus (4) dan perhitungan berikut:

$$
t_{o}=2,23
$$

Dari proses perhitungan diatas dapat diketahui harga $t_{o}$ dari data yang diperoleh adalah sebesar 2,23 . Untuk mengetahui adakah signifikasi atau perbedaan hasil belajar pada siswa yang mengikuti les dan tidak mengikuti les pada mata pelajaran IPA, selanjutnya harga $t_{o}$ tersebut di interpretasikan pada taraf signifikasi $5 \%$ dan pada taraf signifikasi $1 \%$ untuk $t_{\text {tabel }}$. Berhubung penelitian yang diambil adalah mengenai pengaruh les pada hasil belajar dengan menganalisis signifiknasi nilai PTS IPA KI-4 dari siswa yang mengikuti les dan tidak mengikuti les maka dalam menentukan nilai $t_{\text {tabel }}$ menggunakan uji dua pihak. Langkah pertama untuk menentukan $t_{\text {tabel }}$ adalah menentukan Degree Of Freedom (df). Untuk menentukan df menggunkan rumus:

$d f=N_{x}+N_{y}-2(2$ diperoleh dari 2 variabel yang ada yaitu $\mathrm{x}$ dan $\mathrm{y})$

$$
\begin{gathered}
d f=(14+11)-2 \\
d f=23
\end{gathered}
$$

df yang diperoleh yaitu 23. Selanjutnya diperolehlah $t_{\text {tabel }}$ untuk taraf signifikasi $5 \%$ pada uji dua arah adalah 2,069. Sedangkan untuk mengetahui mengetahui hipotesis penelitian maka hasil dari t hitung 
di bandingkan dengan $t_{\text {tabel }}$. Jika nilai t hitung $\geq t_{\text {tabel }}$ maka $H_{0}$ ditolak. Dan jika t hitung $\leq t_{\text {tabel }}$ maka $H_{0}$ diterima. Dengan demikian dapat diketahui dengan $t_{o} 2,23$ pada taraf signifikasi 5\% adalah 2,069< 2,23 dalam arti $t_{\text {tabel }}$ lebih kecil dari nilai t hitung atau t hitung $\geq t_{\text {tabel }}$. Maka dari hasil analisis ini $H_{0}$ yang menyatakan bahwa tidak terdapat signifiknasi nilai IPA siswa ditolak. Sedangkan $H_{1}$ yang menyatakan adanya signifiknasi nilai IPA siswa yang mengikuti les diterima.

Dengan ditolaknya $H_{0}$ maka dapat disimpulkan adanya signifiknasi nilai antara siswa yang mengikuti les dengan siswa yang tidak mengikuti les. Dengan itu pula, maka dapat disimpulkan jika les atau bimbingan belajar di luar jam sekolah ini mampu meningkatkan hasil belajar IPA siswa. Pengujian yang terkait dengan hubungan antara pengetahuan dan prestasi belajar juga dilakukan oleh Ahvan and Pour (2016) dan Laidra, Pullmann, dan Allik (2007). Ahvan and Pour (2016) memperkirakan wawasan 270 siswa sekolah menengah menggunakan instrumen jajak pendapat Douglas dan Damage yang terdiri dari 80 hal penjelasan. Hasil tinjauan ini menunjukkan bahwa ada hubungan positif dan kritis $(\mathrm{p}<0,05)$ antara pengetahuan dan prestasi belajar siswa sekolah menengah di Bandar Abbas. Wawasan siswa yang diperkirakan menggunakan instrumen Raven's Standard Moderate Networks berlaku untuk menunjukkan bahwa hubungan antara pengetahuan dan prestasi belajar adalah hubungan yang positif dan besar ( $\mathrm{p}<$ 0,001 ), sehingga cenderung disimpulkan bahwa wawasan adalah indikator yang layak dari prestasi belajar. di semua kelas.

Dari penjelasan di atas, cenderung dianggap bahwa indikator ketuntasan belajar sangat penting untuk diperhatikan. Oleh karena itu, tinjauan ini berencana untuk melihat dampak dari faktor ketersediaan dan wawasan pembelajaran terhadap prestasi siswa. Spekulasi yang diajukan adalah adanya pengaruh status belajar dan wawasan terhadap prestasi belajar siswa.

\section{KESIMPULAN}

Berdasarkan data yang telah penulis kumpulkan yaitu berupa dokumentasi hasil nilai belajar siswa kelas VIIII MTs Jabal Noer TA 2020-2021 yang kemudian diolah dan dianalisis, hasilya menunjukkan bahwa bimbingan belajar ini memiliki pengaruh terhadap hasil belajar siswa yang dalam hal ini adalah hasil belajar mata pelajaran IPA. Hal ini terbukti dengan adanya signifikasi nilai antara siswa yang mengikuti les dengan siswa yang tidak mengikuti les dengan signifikasi $5 \%$. Dari nilai $t_{o}=2,23$ yang dibandingkan dengan $t_{\text {tabel }} 2,069$, maka $t_{o}$ lebih besar dari pada $t_{\text {tabel }}$. Dengan ini maka $H_{0}$ yang menyatakan tidak adanya signifiknasi antara nilai siswa yang mengikuti les dengan siswa yang tidak mengikuti les ditolak. Ini berarti ada pengaruh les tersebut terhadap siswa yang mengikuti les pada mata pelajaran IPA

\section{REFERENSI}

Ahvan, Y. R., \& Pour, H. Z. (2016). The correlation of multiple intelligences for the achievement of secondary students. Educational Research and Reviews. 11(4), 141-145.

Amti, Erman dan Prayitno. 2004. Layanan bimbingan dan konseling kelompok. Padang: Jurusan Bimbingan dan Konseling Fakultas Ilmu Pendidikan Universitas Negeri Padang.

Arief S. Sadiman.2009. Media Pendidikan: Pengertian, Pengembangan dan Pemanfaatannya. Jakarta: Rajawali Pres. 
Arikunto, S. 2010. Prosedur Penelitian Suatu Pendekatan Praktik. Jakarta: Rineka Cipta.Fauziyyah, Muthi dan Usmi, Karyani. 2017. "Kesejahteraan Siswa: Studi Komaratif Siswa Bedasar Keikutsertaan Kegiatan Tahfidz“. Jurnal Ilmiah Psikologi. 2(2) : 195.

Fauziyyah, Muthi dan Usmi, Karyani. 2017. "Kesejahteraan Siswa: Studi Komaratif Siswa Bedasar Keikutsertaan Kegiatan Tahfidz“. Jurnal Ilmiah Psikologi. 2(2) : 195.

Gagne, R.M. (1977). The Condition of Learning 3rd edition. New York: Holt Rinehart and Winston Inc.

Hamalik, Oemar. 1990. Sistem Intership Kependidikan Teori dan Praktek. Bandung : Mandar Maju.

Irwanto. 1997. Psikologi Umum. Jakarta: PT. Gramedia Pustaka Utama

Jensen,A.S. The Nature of Intelligence and Its Relation to Learning, Journal of Research and Development in Education, Vol. 12, Number 2, 1979

Kazu, I.Y. (2009). The effect of learning style on education and the teaching process. Journal of Social Sciences. 5(2). 85-94.

Kemendikbud. 2013. Peraturan Pemerintah No 54 Tahun 2013 Tentang Standar Kompetensi Lulusan. Jakarta: Kementerian Pendidikan dan Kebudayaan Republik Indonesia.

Pemerintah Republik Indonesia, 2010. Peraturan Pemerintah Republik Indonesia Nomor 17 tahun 2010 tentang Pengelolaan dan Penyelenggaraan Pendidikan. Jakarta

Slameto. 2010. Belajar dan Faktor-Faktor yang Mempengaruhinya. Jakarta:Rineka Cipta.

Soemanto, Wasty. 1998. Psikologi Pendidikan. Bandung: Rineka Cipta.

Sugiyono. 2007. Metode Penelitian Kuantitatif Kualitatif dan R\&D. Bandung: Alfabeta.

Triastuti, N. J. (2016). The infl uence of self directed learning readiness and self study on academic achievement of medical students. International Journal Innovation and Scientific Research, 533-537. Diunduh dari http://www.ijisr.issr-journals.org/ abstract.php?article=IJISR-16-217-02 .

Undang-undang Republik Indonesia, No. 2 Tahun 1989 tentang Sistem Pendidikan Nasional dan Penjelasannya, Departemen Pendidikan dan Kebudayaan Repub1ik Indonesia, 1989

Winkel. 2012. Psikologi Pengajaran. Yogyakarta : Media Abadi 